\title{
Pembeli adalah Raja: Strategi Komunikasi Pemasaran Konvensional Warung Spesial Sambal Menghadapi Persaingan Pasar Modern
}

\author{
Infra Wahdaniah ${ }^{1}$, Afrina Sari ${ }^{2}$ \\ 1,2Universitas Budi Luhur, Jakarta - Indonesia
}

\begin{abstract}
ABSTRAK
Strategi komunikasi pemasaran konvensional masih bisa diandalkan di tengah persaingan bisnis dan pasar modern, dengan menggunakan slogan pembeli adalah raja. Strategi komunikasi pemasaran merupakan hal yang sangat penting dan menjadi ujung tombak bagi sebuah perusahaan yang memproduksi barang maupun jasa. Penelitian ini menggunakan metode kepustakaan dengan mengumpulkan bahan kepustakaan berupa buku, jurnal, karya ilmiah, dan lain sebagainya, membuat catatan untuk mempermudah penyusunan hasil penelitian. Data yang diperoleh dikompulasi, dianalisis, dan disimpulkan sehingga memperoleh kesimpulan mengenai strategi pemasaran konvensional di tengah persaingan bisnis dan pasar modern. Hasil penelitian menunjukkan, usaha tanpa strategi pemasaran dapat bertahan di era modern ini dengan model pemasaran konvensional. Waroeng SS menjadi bukti bahwa ketidaktaatan terhadap teori dengan menerapkan slogan konvensional "Pembeli adalah raja", memberikan nilai promosi dari mulut ke mulut hingga membuktikan keberhasilan usaha warung makanan tersebut. Produksi mengalami peningkatan dengan jumlah outlet yang terus bertambah dan pendapatan yang semakin besar.
\end{abstract}

Kata kunci: strategi komunikasi; pemasaran konvensional; pasar modern; pembeli adalah raja; waroeng ss

\section{Buyers is a King: Warung Special Sambal's Conventional Marketing Communication Strategy in Facing Modern Market Competition}

\begin{abstract}
Conventional marketing communication strategies can still be relied upon in the midst of modern business and market competition, using the slogan 'buyer is a king'. Marketing communication strategy is very important and becomes the spearhead for a company that produces goods and services. This research uses the literature review method by collecting literature materials in the form of books, journals, scientific papers, etc., making notes to facilitate the preparation of research results. Then the data obtained are compiled, analyzed, and concluded so as to obtain conclusions about conventional marketing strategies in the midst of business competition and modern markets. The result shows that businesses without a marketing strategy can survive in this modern era with conventional marketing models. Waroeng SS is proof that disobedience to the theory by applying the conventional slogan "The buyer is a king" provides promotional value by word of mouth to prove the success of the food stall business. Production has increased with the number of outlets that continue to grow and income is getting bigger
\end{abstract}

Keywords: conventional marketing; communication strategy; buyer is a king; waroeng ss; modern market 


\section{PENDAHULUAN}

Di era modern sekarang, pemasaran seringkali disebutkan sebagai ujung tombak sebuah perusahaan yang memproduksi barang maupun jasa. Pemasaran memerlukan berbagai pengembangan dan strategi secara terus menerus untuk memenangkan keunggulan bersaing hingga mencapai hasil berkesinambungan. Itulah salah satu alasan strategi pemasaran dipandang sebagai suatu dasar yang digunakan dalam menyusun perencanaan perusahaan secara paripurna.

Sebagai ujung tombak perusahaan, dalam pemasaran dibutuhkan perencanaan menyeluruh. $\mathrm{Hal}$ ini mengingat adanya potensi-potensi permasalahan termasuk kemungkinan terjadinya hambatan sehingga menyebabkan tidak efektifnya pemasaran. Pemasaran yang tidak efektif akan menjadi hambatan serius dalam pengembangan perusahaan secara berkesinambungan. Seiring perkembangan jaman, dibutuhkan strategi komunikasi pemasaran yang kreatif. Apalagi dengan kemajuan teknologi informasi, jika tidak mampu mengimbangi perkembangan yang ada, tidak hanya pemasaran yang tertinggal, tetapi perusahaan pun akan ditinggalkan pelanggan dan semakin tertinggal jauh dari pesaing. Komunikasi pemasaran secara langsung, melalui media sosial menjadi pilihan rasional saat ini, dengan pertimbangan akan efektif dan juga efisien.

Perkembangan teknologi yang pesat mendorong pengusaha menjadikan media sosial sebagai salah satu pilihan untuk pemasaran. Salah satu pertimbangannya, berdasarkan laporan Hootsuite (Januari 2020) yang dikutip Kompas.id, pengguna media sosial di Indonesia saat ini mencapai 160 juta orang. Jumlah itu meningkat 12 juta (8,1 persen) antara April 2019 hingga Januari 2020. Diperkirakan jumlah itu terus mengalami peningkatan (Kompas.id, 2020).

Media sosial yang semula digunakan untuk tujuan komunikasi kini berkembang menjadi media pemasaran, promosi yang sangat efektif. Dalam kutipan lain di media yang sama disebutkan pertumbuhan pengguna internet 175,4 juta di Indonesia hingga Januari 2020. Pengguna bertambah 25 juta (17 persen) antara 2019 dan 2020. Sementara penetrasinya di Indonesia mencapai 64 persen pada Januari 2020 (Kompas.id, 2020).

Perkembangan pengguna media sosial ini membuka peluang promosi melalui media baru yang sebelumnya belum dikenal masyarakat. Bukan tidak mungkin media sosial akan menguasai pasar promosi sehingga mengambil ceruk pariwara yang selama ini dinikmati media-media mainstream seperti televisi, radio dan media cetak.

Meski begitu ternyata tidak semua jenis usaha mutlak harus menggunakan strategi pemasaran yang modern dan teoritis seperti definisi para ahli atau melibatkan pihak ketiga. Bahkan berkecenderungan tidak mengenal strategi pemasaran yang wajar di jaman sekarang. $\mathrm{Hal}$ ini merupakan pengecualian dan belum tentu bisa menghasilkan kualitas sama ketika 
dipraktikkan secara umum, meskipun bukti empiris menunjukkan fakta demikian.

Salah satu di antaranya adalah strategi yang diterapkan warung Spesial Sambel (SS) dengan mengusung semboyan strategi pemasaran "Pembeli adalah Raja". Kalimat yang sudah akrab dengan semua orang terutama yang terjun di dunia usaha itu terbukti membuat usaha warung makanan yang dirintis pertama kali di Yogyakarta tersebut berkembang pesat.

Usaha makanan tersebut bisa membuktikan cara yang dilakukan dengan menerapkan strategi konvensional yang sangat dipahami oleh dunia usaha bahkan semua orang, atau tanpa pemasaran modern, sangat memadai. Dengan memanfaatkan konsumen yang datang, terbukti mampu mendongkrak performance perusahaan secara maksimal. Penambahan outlet yang signifikan dengan penyebaran masif memberi bukti, strategi yang dilakukan oleh pelaku usaha sangat efektif. Model komunikasi pemasaran konvensional tetap efektif dan masih bisa bersaing di era modern. Atas dasar diskripsi tersebut, penelitian ini ingin mengetahui, bagaimana usaha dengan model pemasaran konvensional dapat bertahan tanpa strategi pemasaran di era modern ini?

Pembeli adalah raja merupakan slogan lama yang hampir pasti pernah didengar luas oleh masyarakat. Para wirausaha yang bergerak di bidang produksi maupun jasa, memegang prinsip itu, meskipun kenyataannya tidak mudah untuk mengimplementasikan makna dari slogan tersebut.

Dari bisnis emperan, warung, kios, toko, mini market hingga hypermarket dapat dipastikan semua paham kalimat tersebut. Para konsumen yang datang diberikan pelayanan bagaikan raja. Pemilik usaha sadar mereka adalah pihak yang harus memberikan pelayanan terbaik kepada raja yang datang. Dengan pelayanan layaknya raja, maka konsumen maupun pelanggan akan datang kembali ke tempat usaha bahkan mengabarkan berita itu kepada sahabat-sahabatnya.

Belum ada batasan teori yang baku atas slogan "pembeli adalah raja" sehingga dapat dimaknai secara hermeneutic. Masing-masing mempunyai terjemahan yang beragam dengan mengimplementasikan apa yang dimaksud secara umum. Dengan konsep menerapkan slogan tersebut, kabar itu akan tersebar dari "mulut ke mulut" sebagai suatu bentuk promosi yang sangat baik.

Dalam pemahaman positif, arti slogan itu adalah sangat baik, memberikan keleluasaan bagi konsumen ataupun pelanggan untuk menuruti keinginannya dalam berbelanja. Bukan sekadar kebutuhan melainkan memenuhi keinginan masing-masing. Tapi dari makna lain, justru para konsumen sebetulnya dibiarkan lebih lelah. Karena harus melayani dirinya sendiri mulai dari memilih barang, mengambil barang, membawa kemana-mana berkeliling hingga ke kasir untuk membayarnya. Tapi pelanggan ataupun konsumen memang tidak hanya memenuhi apa yang diperlukan saat itu tetapi lebih banyak karena keinginannya. 
Pemasaran pada dasarnya merupakan kata yang memiliki makna luas, termasuk di dalamnya adalah promosi. Dalam batasan teoritis dikemukakan oleh sejumlah ahli diantaranya Tjiptono. Dia menyebutkan promosi pada dasarnya adalah suatu bentuk komunikasi pemasaran dengan menyebarkan informasi, mempengaruhi/membujuk, dan atau mengingatkan pasar sasaran atas usaha perusahaan serta produknya agar konsumen bersedia menerima, membeli, dan loyal pada produk yang ditawarkan (Tjiptono 2007).

Konvensional adalah hal yang secara umum bersifat mengikuti kebiasaan-kebiasaan lazim digunakan atau berdasarkan kesepakatan oleh banyak orang. Misalnya, adalah kebiasaan yang sudah berjalan lama di satu tempat. Kebiasaan itu sudah menjadi tradisi lama sehingga sudah umum atau semua orang dianggap telah mengetahui.

Strategi menurut Marrus dalam Umar (2001) didefinisikan sebagai suatu proses penentuan rencana para pemimpin puncak yang berfokus pada tujuan jangka panjang organisasi, disertai penyusunan suatu cara atau upaya bagaimana agar tujuan tersebut dapat dicapai. Definisi lain dari Prahalad dalam Umar (2001) menyebutkan tindakan bersifat incremental (senantiasa meningkat) yang dilakukan terus menerus berdasarkan sudut pandang tetap, apa yang diharapkan para pelanggan pada masa yang akan datang (umar, 2001).

Dengan demikian kalau strategi konvensional didefinisikan secara singkat, bisa bermakna apa yang dilakukan merupakan tindakan yang lumrah, bukan lagi disebut strategi karena orang sudah mengetahui semua sebagai kebiasaan pada umumnya. Namun, kata konvensional juga didefinisikan sebagai sesuatu yang secara umum sebagai ketinggalan jaman (kuno) atau cara tradisional yang sudah tidak sesuai kondisi aktual jaman sekarang.

Makna itu sebenarnya tidak tepat, karena sebenarnya kata konvensional selalu berhubungan dengan kesepakatan para pihak. Berdasarkan etimologi, kata konvensional berasal dari kata konvensi, artinya kesepakatan atau permufakatan yang dibuat oleh sejumlah orang. Jadi konvensi atau kesepakatan ini bisa dalam organisasi tertentu, daerah tertentu, maupun negara. Istilah konvensional itu bermakna terhadap hal-hal yang dilakukan dengan didasari kesepakatan umum.

Persaingan Bisnis dapat dikatakan sempurna apabila terdapat sejumlah besar penjual dan pembeli komoditi, sedemikian rupa sehingga tindakan dari seorang individu tidak dapat mempengaruhi harga komoditi tersebut (Utomo, 2010). Produk dari seluruh perusahaan di dalam pasar bersifat homogeny dan terdapat mobilitas sumber daya yang sempurna. Selain itu konsumen, pemilik produksi maupun perusahaan di dalam pasar punya pengetahuan sempurna terhadap harga dan biaya saat itu (Michael E. Porter dalam Jatmiko, 2004).

Pasar Modern adalah tempat terjadinya jual beli barang yang harganya telah ditentukan secara sepihak oleh pengelola pasar dengan teknis swalayan melalui konsep profesional dan 
kualitas untuk menarik konsumen sebayak-banyaknya (Nelarianty, 2013).

Desain bangunan pasar modern sejak awal telah mempertimbangkan keterpaduan dan kenyamanan konsumen. Diantaranya tersedianya lahan parkir, ruang yang nyaman, kemudahan akses dengan transportasi umum maupun pribadi serta pemilahan jenis barang, dan pelayanan yang memanjakan konsumen dengan model self service. Tujuannya memberi kepuasan kepada pelanggan. Kottler (1997) mendefinisikan kepuasan pelanggan sebagai tingkat perasaan dimana seseorang menyatakan hasil perbandingan antara kinerja produk (jasa) yang diterima dengan yang diharapkan.

Pasar modern yang dimaksud dalam konsep ini cenderung mengarah kepada pasar modern berjenis ritel, bukan pasar khusus makanan seperti restoran. Karena pada pasar modern yang menjual makanan dalam bentuk siap saji kebanyakan menerapkan pelayanan bukan swalayan. Justru restoran atau warung makan tradisional mengusung konsep swalayan. Jadi konsep pasar modern yang menjual makanan justru menerapkan model pelayanan sedangkan konsep pasar tradisional yang menjual makanan banyak dengan menerapkan swalayan.

\section{METODE PENELITIAN}

Penelitian ini menggunakan metode kepustakaan, meliputi persiapan peralatan tulis yang diperlukan, menyusun bibliografi, mengatur waktu dan jadwal dan mengumpulkan bahan kepustakaan berupa buku, jurnal, karya ilmiah dan lainnya serta membuat catatan agar mempermudah penyusunan hasil penelitian (Khatibah, 2011). Penelitian kepustakaan adalah penelitian yang dilakukan hanya berdasarkan atas karya tertulis, termasuk hasil penelitian yang telah maupun yang belum dipublikasikan (Embun, 2012). Jenis data yang digunakan adalah data sekunder. Selanjutnya, data yang diperoleh dikompilasi, dianalisis, dan disimpulkan sehingga memperoleh kesimpulan mengenai strategi pemasaran konvensional di tengah persaingan bisnis dan pasarmodern.

\section{HASIL DAN PEMBAHASAN}

Kehidupan modern menuntut pemenuhan kebutuhan sehari-hari serba praktis. Semua pekerjaan dituntut selesai dengan cepat dan tepat dan hemat biaya. Para penyedia jasa dan produksi pun berlomba memberi janji terbaik kepada konsumen termasuk memberikan bonus, promo, kenyamanan dan lainnya.

Pemasaran, promosi dan ajang perkenalan lain menjadi salah satu kegiatan primadona perusahaan yang selalu disiapkan sebagai salah satu pos anggaran yang sangat besar. Tujuannya adalah memikat konsumen menjadi tertarik membeli produk atau menikmati 
jasa yang mereka tawarkan. Promosi dan pemasaran merupakan satu hal yang tidak bisa dihilangkan dalam kegiatan bisnis modern. Dalam bidang apa pun, pemasaran dan promosi dianggap mampu mendorong pergerakan usaha secara cepat dan selalu mengikuti perkembangan keadaan. Tujuannya adalah tidak tertinggal dari pesaing lain dengan berbagai inovasi. Promosi melalui media massa, televisi radio, media cetak, internet dan yang sekarang menjadi primadona baru melalui media sosial.

Meskipun demikian, tidak semua promosi dan teknik komunikasi pemasaran dengan berbagai janji kenyamanan, berbagai sarana teknologi yang memadai selalu memberikan keberhasilan dalam sebuah produk dan jasa. Sebaliknya, tidak semua cara-cara tradisional selalu tertinggal dari yang modern.

Usaha Waroeng SS (Spesial Sambal) telah membuktikan. Usaha makanan ini tidak melakukan promosi sama sekali kepada konsumen atau calon konsumen. Perusahaan yang berdiri pada tahun 2002 itu terus berkembang melaju meninggalkan banyak pesaingnya dengan omzet miliaran rupiah. Memiliki gerai lebih dari 80 outlet yang tersebar di 45 kota di Jawa dan Bali diperkuat dengan 3600 karyawan (Afif, 2018).

Warung makan ini tidak pernah melakukan promosi di media, termasuk media sosial. Kalau pun ada yang mewartakan di media atau media sosial, itu murni dari keinginan warga sendiri atau media bukan kemauan pihak pengusaha. Slogan Konsumen adalah raja menjadi landasan utama dalam memberikan pelayanan kepada pelangganya.

Mengusung konsep yang sudah diketahui sebagai slogan umum "Pembeli adalah Raja" ternyata menjadi landasan yang kuat dalam menciptakan citra rasa usaha makanan ini. Konsep-konsep lain yang menjadi pedoman adalah pengembangan dari konsep dasar yang sudah diketahui umum tetapi dianggap konvensional atau bahkan tradisional. Ternyata konsep modern yang dilandasi teori-teori akademis telah dimiliki penggagas pertama berdirinya warung ini. Tidak sekadar usaha yang minim perhitungan, melainkan dengan perencanaan terukur selain adanya pengalaman pengelolaan usaha sebagai pemula.

Memilih slogan "Pembeli adalah Raja" dengan memanfatkan peran pelanggan untuk berpromosi dari mulut ke mulut merupakan strategi lanjutan dari perencanaan manajemen usaha Waroeng SS. Sekalipun belum pernah melakukan promosi (Afif: 2018), usaha ini memiliki dasar manajemen yang secara teoritis memenuhi konsep-konsep sangat dalam.

Promosi pada dasarnya adalah suatu bentuk komunikasi pemasaran yang merupakan aktivitas promosi dengan berusaha menyebarkan informasi, mempengaruhi/membujuk, dan atau meningatkan pasar sasaran atas usaha perusahaan serta produknya agar bersedia menerima, membeli, dengan loyal pada produk yang ditawarkan perusahaan yang bersangkutan (Tjiptono, 2007). 
American Marketing Association (AMA) sebagaimana dikutip Kotler dan Keller mendefinisikan pemasaran sebagai seni dan ilmu memilih pasar sasaran untuk mendapatkan, menjaga, serta menumbuhkan pelanggan dengan menciptakan dan menyerahkan maupun mengkomunikasikan nilai pelanggan yang unggul. Mengacu pada definisi tersebut maka pemasaran merupakan suatu proses dari perencanaan, pengarahan, pengendalian produk maupun jasa melalui penetapan harga, distribusi serta promosinya dengan tujuan membantu organisasi dalam mencapai sasarannya (Kotler dan Keller, 2007). Segmentasi pasar merupakan proses membagi pasar ke dalam kelompok pembeli yang berbeda-beda menurut kebutuhan, karakteristik, atau perilaku yang membutuhkan bauran produk dan bauran pemasaran, atau merupakan segmentasi pasar untuk mengetahui bahwa setiap pasar terdiri atas beberapa segmen yang berbeda-beda (Setiadi. 2003).

Penentuan pasar sasaran yaitu pemilihan luasnya segmen sesuai kemampuan suatu perusahaan memasuki segmen tersebut. Dalam menelaah pasar sasaran harus mengevaluasi tiga faktor (Umar, 2001), yaitu ukuran dan pertumbuhan segmen, daya tarik struktural segmen, sasaran dan sumber daya. Penentuan posisi pasar (positioning) sebagai strategi merebut posisi dibenak/hati konsumen, sehingga strategi ditujukan untuk membangun kepercayaan, keyakinan, dan kompetensi bagi pelanggan juga penting. Ini sangat terkait dengan slogan "Pembeli adalah Raja" sehingga akan dimanfaatkan sebagai media promosi dari mulut ke mulut. Hal ini sesuai dengan apa yang dikemukakan Philip Kotler, positioning merupakan aktivitas mendesain citra dan memposisikan diri di benak konsumen.

Dalam hal bauran pemasaran (marketing mix) pada konsep Waroeng SS yaitu memadukan empat aspek (4P) yang dikemukakan Kotler dan Armstrong (2004), yaitu kumpulan alat pemasaran taktis terkendali, dipadukan oleh perusahaan dengan tujuan untuk menghasilkan respon yang diinginkannya di pasar sasaran. Bauran pemasaran empat $P(4 P)$ itu adalah product, merupakan kombinasi barang dan jasa yang ditawarkan kepada pasar sasaran. Elemen yang termasuk dalam bauran produk ini diantaranya adalah ragam produk, kualitas, design, fitur, nama merek, kemasan, serta layanan.

Berikutnya adalah price. Harga merupakan jumlah uang yang harus dibayarkan pelanggan guna memperoleh produk. Harga merupakan satu-satunya unsur bauran pemasaran yang menghasilkan pendapatan, sedangkan unsur-unsur lainnya menghasilkan biaya. Place atau tempat meliputi kegiatan perusahaan mulai dari membuat produk hingga distribusi yang menurut Kotler merupakan rangkaian organisasi yang saling tergantung dalam proses menjadikan suatu produk atau jasa siap digunakan atau dikonsumsi (Kotler, 2005).

Terakhir adalah promotion, merupakan aktivitas menyampaikan produk dan membujuk pelanggan untuk membelinya. Dalam konsep Waroeng SS, promosi merupakan hasil dari proses yang menghasilkan "bonus" berupa promosi. Artinya, Waroeng SS tidak pernah membujuk konsumennya untuk membeli produknya tetapi memberikan bukti kepada 
pelanggan bahkan mengajak pelanggan lain yang dikabarkan dari mulut ke mulut. Konsepkonsep teoritis hampir semua dipenuhi oleh SS kecuali promosi yang didapat sebagai bonus dari konsep yang terencana dan dijalankan dengan baik. Strategi ini mampu beradaptasi bahkan unggul dalam persaingan di pasar modern yang memanfaatkan teknologi informasi maupun media sosial.

Manajemen dasar yang diterapkan Waroeng SS pada dasarnya sama dengan prinsip pemasaran produk atau jasa lain. Bahkan terhadap produk nonmakanan seperti pakaian harus memenuhi prinsip dasar sebagaimana dikemukakan Kotler, yaitu segmentasi pasar (segmentation), strategi penentuan pasar sasaran (targeting), dan strategi posisi pasar (positioning). Selain itu juga marketing mix 4P, meliputi unsur produk (product), harga (price), tempat (place) dan promosi (promotion). Misalnya, produk Batik Diajeng Solo, konsep pemasaran Kotler menjadi andalan dalam menunjang pemasarannya. Namun jenis produk dan target pasar berbeda, maka model pemasaran dan promosi dilakukan dengan cara yang modern seperti penggunaan jejaring media sosial, karena pada dasarnya strategi pemasaran sebagai salah satu dasar menyusun perencanaan perusahaan secara menyeluruh (Wibowo dkk, 2015).

Pada dasarnya konsep-konsep demikian bisa jadi berlaku bagi pemasaran produk dan jasa secara umum tanpa membeda-bedakan. Meskipun dengan berkembangnya teknologi informasi, konsep itu perlahan mengalami pengikisan. Setidaknya adanya penjualan produk dan jasa melalui online yang seringkali kurang mempertimbangkan soal tempat.

Dibandingkan dengan sesama produk makanan, misalnya Pizza Hut sebagai restoran yang telah punya nama mendunia, apa yang dilakukan Waroeng SS bisa disebut sebuah anomali. Pizza Hut tetap melakukan promosi, bahkan melakukan inovasi dengan penjualan secara asongan selama pandemi ini. Padahal, Pizza Hut merupakan produk global yang sudah berdiri sejak 1958 dan menjadi simbol pelayanan jasa terbaik dari Maine sampai Hawaii, dari Australia sampai Kepulauan Virginia, dan dari Taiwan sampai Indonesia. Pada tahun 2012 cabang Pizza Hut sudah mencapai 12.000, tersebar di 84 negara dengan produksi per harinya sekitar 1,7 juta pizza untuk empat juta pelanggan (Sundalaghi, 2012).

Konsep usaha Woroeng SS menurut Yoyok Hery W. mengendepankan prinsip motivasi untuk bertahan hidup dengan memperbaiki keadaan ekonomi keluarga pada saat awal pendirian (Afif, 2018). Motivasi untuk bisa membiayai sekolah dirinya dan adik-adiknya. Prinsip mengedepankan "Pembeli adalah Raja" merupakan slogan promosi tanpa berbayar. Meskipun sebenarnya tanpa disadari segala aspek marketing sudah tercakup di dalamnya termasuk marketing mix. Pemilihan produk sambal karena tidak ada orang Indonesia yang tidak mengenal sambal. Orang makan sambal akan menemukan sensasi tidak nyaman tetapi mebuat kecanduan. 
Soal harga juga menjadi perhatian dalam pendirian awal Waroeng SS ini. Sebagai mahasiswa, pendiri mampu mengukur keuangan mahasiswa sehingga penerapan harga menjadi salah satu pertimbangan dengan standar keuntungan rendah tetapi tidak merugi. Mengenai tempat, pemilihan lokasi dengan mempertimbangkan konsumen yang menjadi target yaitu mahasiswa di sekitar tempat pertama kali Waroeng SS membuka usaha.

Pilihan tempat yang tepat menginisiasi pembukaan cabang kedua, ketiga, dan seterusnya. Tentang strategi prinsip pelayanan "Pembeli adalah Raja" memberi nilai promosi tidak berbayar dengan penyebaran dari mulut ke mulut konsumennya. Diakui, hingga saat ini Waroeng SS belum pernah berpromosi untuk memikat konsumen secara khusus.

\section{SIMPULAN}

Perencanaan usaha dalam bentuk produksi maupun jasa menjadi hal yang penting, dan tahap awal dalam membangun usaha. Pemasaran yang di dalamnya antara lain terdapat kegiatan promosi disadari atau tidak menjadi hal penting. Sejumlah teori dari para ahli tentang konsep komunikasi pemasaran maupun promosi menjadi bukti tentang perlunya kegiatan tersebut. Teori-teori yang diajukan tentu saja telah dibuktikan melalui berbagai kajian empiris.

Namun tidak semua usaha yang menerapkan teori sepenuhnya terlepas dari kegagalan. Sebaliknya, tidak semua usaha yang tidak mengindahkan teori akan gagal. Usaha yang menerapkan teori sepenuhnya bisa gagal karena adanya faktor tertentu yang tidak imbang. Demikian pula, usaha yang tidak mengindahkan teori promosi bisa saja berhasil karena ada faktor lain yang dominan hingga menciptakan keberhasilan. Kenyataannya, usaha tanpa strategi pemasaran dapat bertahan di era modern ini dengan model komunikasi pemasaran konvensional.

Waroeng SS menjadi bukti bahwa ketidaktaatan terhadap teori dengan menerapkan slogan konvensional "Pembeli adalah Raja" ternyata memberikan nilai promosi dari mulut ke mulut hingga membuktikan keberhasilan usaha warung makanan. Produksi meningkat dengan jumlah outlet yang terus bertambah dan pendapatan yang semakin besar.

\section{DAFTAR PUSTAKA}

Afif, M,, Arifa, I. (2018). Analisis Kelayakkan Bisnis, Strategi Pemasaran dan Modal Reliji pada Usaha Waroeng Spesial Sambal Yogyakarta. Jurnal Ekonomi Syariah Indonesia, 8(1), 37-49.

Essy, S. (2007). Pembeli adalah Raja: Kasus Swalayan, Jurnal Ilmu Budaya, 4(1), 65. 
Kompas.id. (2020). Media Sosial, Tak Sekadar Jaringan Pertemanan, 17 Juni 2020.

Kotler, A. (1997). Prinsip-Prinsip Pemasaran. Jakarta: Erlangga.

Kotler, P., Armstrong, G. (2004). Dasar-Dasar Pemasaran, Jakarta: Penerbit Indeks.

Kotler, P. (2005). Manajemen Pemasaran. Jakarta: Indeks Media Group.

Kotler, P., Keller. (2007). Manajemen Pemasaran, Jakarta: PT. Indeks.

Kurniawati, Dewi., Arifin, N. (2015). Strategi Pemasaran Melalui Media Sosial dan Minat Beli Mahasiswa. Jurnal Simbolika, 1(2).

Nelariyanti. (2013). Analisis Perbedaan Pasar Modern dan Pasar Tradisional Ditinjau dari

Strategi Tata Letak (lay out) dan Kualitas Pelayanan untuk Meningkatkan Posisi Tawar

Pasar Tradisional. Jurnal Manajemen \& Bisnis. 13(01).

Setiadi, N.J. (2003). Perilaku Konsumen: Konsep dan Implikasi untuk Strategi dan Penelitian Pemasaran. Jakarta: Kencana.

Sindalaghi, M. (2014). Kualitas Produk, Daya Tarik Iklan, dan Potongan Harga terhadap Minat Beli Konsumen Pada Pizza Hut Manado, Jurnal EMBA, 2(1).

Tjiptono, F. (2007). Strategi Pemasaran. Yogyakarta: Penerbit Andy.

Tri, J.U. (2010). Lingkungan Bisnis dan Persaingan Bisnis Ritel. Jurnal Fokus Ekonomi, 5(1).

Umar, H. (2001). Strategic Management in Action, Konsep, Teori, dan Teknik Menganalisis Manajemen Strategis Strategic Business Unit. Berdasarkan konsep Michael R. Porter, Fred R. David, dan Wheelan Hunger, Jakarta: PT. Gramedia Pustaka Utama.

Wibowo, D.H., Arifin, Zainul, Sunarti. (2015). Analisis Strategi Pemasaran untuk Meningkatkan Daya Saing UMKM (Studi pada Batik Diajeng Solo). Jurnal Administrasi Bisnis (JAB). 29(1). 